\title{
EFFECT OF THE AGGREGATE TYPE ON THE PROPERTIES OF ALKALI-ACTIVATED SLAG SUBJECTED TO HIGH TEMPERATURES
}

\author{
VPLIV VRSTE AGREGATA NA LASTNOSTI Z ALKALIJO \\ AKTIVIRANE ŽLINDRE, IZPOSTAVLJENE VISOKIM \\ TEMPERATURAM
}

\author{
Pavel Rovnaník, Ámos Dufka \\ Faculty of Civil Engineering, Brno University of Technology, Veveří 95, 60200 Brno, Czech Republic \\ rovnanik.p@fce.vutbr.cz \\ Prejem rokopisa - received: 2014-07-24; sprejem za objavo - accepted for publication: 2014-12-08
}

doi:10.17222/mit.2014.116

\begin{abstract}
High temperatures present a risk of destruction for most silicate-based construction materials. Although these materials are not flammable, they lose their properties due to a thermal decomposition. In contrast to ordinary Portland-cement-based materials, alkali-activated slag exhibits a better thermal stability when exposed to temperatures up to $1200{ }^{\circ} \mathrm{C}$. Due to its different porosity it is less susceptible to spalling. However, the properties of the composites after a high-temperature treatment depend also on the stability of the aggregates. The effects of two different types of the aggregate (quartz and chamotte) on the residual mechanical properties and microstructure of the alkali-activated slag mortars exposed to $200-1200{ }^{\circ} \mathrm{C}$ is presented in this study. The results showed an improved mechanical performance of the thermally stable chamotte aggregate at temperatures above $600{ }^{\circ} \mathrm{C}$. $\alpha$-quartz is transformed to $\beta$-quartz at $573{ }^{\circ} \mathrm{C}$, causing a volume instability and, consequently, a strength deterioration. Although chamotte also contains some quartz phase, the reaction of mullite with the alkalis from the matrix leads to the formation of albite and anorthite, making the material tougher and, thus, compensating the negative effect of quartz.

Keywords: alkali-activated slag, high temperatures, chamotte, quartz, strength, microstructure
\end{abstract}

Visoke temperature so tveganje za razpad večine gradbenih materialov, ki temeljijo na silikatih. Čeprav ti materiali niso vnetljivi, izgubijo svoje lastnosti zaradi termične razgradnje. Nasprotno od materialov, ki temeljijo na portland cementu, $\mathrm{z}$ alkalijo aktivirane žlindre izkazujejo boljšo temperaturno obstojnost, če so izpostavljene temperaturam do $1200{ }^{\circ} \mathrm{C}$. Zaradi različne poroznosti so manj občutljive za pojav luščenja. Vendar pa so lastnosti kompozita po visokotemperaturni obdelavi odvisne tudi od stabilnosti agregatov. V študiji so predstavljeni vplivi dveh različnih vrst agregatov (kremen in šamota) na preostale mehanske lastnosti in mikrostrukturo malte iz z alkalijo aktivirane žlindre, izpostavljene temperaturam $200-1200{ }^{\circ} \mathrm{C}$. Rezultati so pokazali izboljšane mehanske lastnosti toplotno stabilnega šamotnega agregata pri temperaturah nad $600{ }^{\circ} \mathrm{C}$. $\alpha$-kremen se transformira pri $573{ }^{\circ} \mathrm{C}$ v $\beta$-kremen, kar povzroči volumensko nestabilnost in posledično poslabšanje trdnosti. Ceprav šamot vsebuje nekaj kremenove faze, reagiranje mulita $\mathrm{z}$ alkalijami iz osnove povzroči nastanek albita in anortita, ki povzročita, da material postane bolj žilav in s tem kompenzira negativni vpliv kremena.

Ključne besede: $\mathrm{z}$ alkalijo aktivirana žlindra, visoke temperature, šamot, kremen, trdnost, mikrostruktura

\section{INTRODUCTION}

Portland cement is today's most commonly used construction material. It owes its widespread utilization to its good mechanical properties, a low cost and a generally good performance. Nonetheless, Portland-cement concrete is not an eternal material and its performance can be affected by several degradation processes, one of which involves high temperatures. Although concrete is not flammable, when exposed to elevated temperatures it partially decomposes and loses its mechanical properties. ${ }^{1-3}$ The second mostly discussed problem about Portland-cement concrete is spalling. This effect is mainly related to the build-up of the pore pressure in consequence of the vaporization of the physically/chemically bound water which results in tensile loading of the microstructure of heated concrete. ${ }^{4-6}$ These two phenomena can be partially eliminated by utilizing alkaliactivated slag as a binder instead of ordinary Portland cement.
Alkali-activated slag (AAS) is a hydraulic binder based on finely ground, granulated blast-furnace slag. Since the slag itself has no hydraulic properties it must be activated with strong alkaline solutions, among which hydroxides, carbonates and especially silicates play the main roles. In contrast to the composites based on Portland cement, alkali-activated slag shows a much better performance when exposed to very high temperatures. ${ }^{7-9}$ Similar to the case of Portland cement, a partial dehydration and decomposition of the binder can be observed up to $600{ }^{\circ} \mathrm{C}$. The principle changes in the microstructure of alkali-activated slag occur between $600{ }^{\circ} \mathrm{C}$ and $800{ }^{\circ} \mathrm{C}$, when the dehydration of the $\mathrm{C}-\mathrm{A}-\mathrm{S}-\mathrm{H}$ phase is complete and new phases start to crystallize, among which akermanite is dominant. Such a significant phase transformation is reflected in the morphology, pore distribution and, especially, in the improvement of the mechanical properties of the alkali-activated slag. ${ }^{8} \mathrm{How}-$ ever, the properties of the composite materials with an 
AAS matrix after a high-temperature treatment also depend on the stability of the aggregates. The effects of two different types of the aggregate (quartz and chamotte) on the residual mechanical properties and microstructure of the alkali-activated slag mortars exposed to 200-1200 ${ }^{\circ} \mathrm{C}$ is presented are this study.

\section{EXPERIMENTAL PART}

\subsection{Materials}

The tested material was prepared with the alkali activation of granulated blast-furnace slag. The slag supplied by Kotouč, s. r. o. (CZ) was ground to a fineness of about $380 \mathrm{~m}^{2} / \mathrm{kg}$ (Blaine). It was a neutral slag with the basicity coefficient $M_{\mathrm{b}}=(\mathrm{CaO}+\mathrm{MgO}) /\left(\mathrm{SiO}_{2}+\mathrm{Al}_{2} \mathrm{O}_{3}\right)$ equal to 1.08 , and its chemical composition in mass fractions (w/\%) was: $\mathrm{SiO}_{2} 39.75, \mathrm{Al}_{2} \mathrm{O}_{3} 6.61, \mathrm{Fe}_{2} \mathrm{O}_{3} 0.46, \mathrm{CaO}$ 39.03, $\mathrm{MgO} 10.45, \mathrm{Na}_{2} \mathrm{O} 0.38, \mathrm{~K}_{2} \mathrm{O}$ 0.63, MnO 0.37, $\mathrm{SO}_{3}$ 0.71. A small amount of merwinite and a trace of quartz were present as the only crystalline phases. Solid sodium water glass having a $\mathrm{SiO}_{2} / \mathrm{Na}_{2} \mathrm{O}$ ratio of 1.95 was used as an alkaline activator. Its chemical composition in mass fractions $(w / \%)$ was: $\mathrm{SiO}_{2} 50.75, \mathrm{Na}_{2} \mathrm{O} 26.78, \mathrm{H}_{2} \mathrm{O}$ 22.47 .

To assess the influence of the aggregate on the stability of the AAS mortar at very high temperatures two types of the aggregate were used. One of them was quartz sand as a type of the commonly used standard materials and the second one was burnt clay, chamotte. The main mineralogical phases found in the chamotte aggregate with an XRD analysis were quartz, cristobalite and mullite.

\subsection{Sample preparation and heat treatment}

Sodium silicate activator was suspended and partially dissolved in water. Then, slag was added and the mixture was stirred in a planetary mixer for about $3 \mathrm{~min}$ to prepare homogeneous slurry. Finally, the aggregate was added into the slurry and stirred to prepare fresh mortar. The amount of the activator added was $20 \%$ of the mass of the slag, the aggregate/slag ratio was 3.0 and a water/ slag ratio of 0.4 was used to achieve an accurate consistency.

The mixes were cast into prismatic moulds of the size of $40 \mathrm{~mm} \times 40 \mathrm{~mm} \times 160 \mathrm{~mm}$. After $24 \mathrm{~h}$ the hardened specimens were immersed into a water bath at $20{ }^{\circ} \mathrm{C}$ for another $27 \mathrm{~d}$. After this period, they were allowed to air dry for another $5 \mathrm{~d}$ before undergoing a high-temperature treatment. The hardened mortars were heated in a Muffle furnace to temperatures of $(200,400,600,800,1000$, and 1200$){ }^{\circ} \mathrm{C}$ at a constant heating rate of $5{ }^{\circ} \mathrm{C} \mathrm{min}^{-1}$. The specimens were kept at the given temperature for $1 \mathrm{~h}$ and then allowed to cool down slowly to room temperature.

The heat-treated specimens were tested for their residual mechanical properties, which were compared with those obtained for the unheated AAS mortar at the age of
28 d. Flexural strengths were determined using the standard three-point-bending test and compressive strengths were measured on the far edge of each of the two residual pieces obtained from the flexural test according to the EN 196-1 standard.

The pore distribution was evaluated by means of a mercury intrusion porosimetry analysis, conducted on the samples using a Micromeritics Poresizer 9300 porosimeter that can generate the maximum pressure of 207 $\mathrm{MPa}$ and can evaluate a theoretical pore diameter of $0.006 \mu \mathrm{m}$. Micrographs of the alkali-activated slag mortars were taken with a TESCAN MIRA3 XMU scanning electron microscope in the SE mode. The experiments were carried out on dry samples that were sputtered with gold and an acceleration voltage of $25 \mathrm{kV}$ was used. $\mathrm{X}$-ray diffraction analyses were carried out using a Bruker D8 advance system equipped with a $\mathrm{Cu}$ tube $\left(\lambda\left(K_{\alpha}\right)=0.154184 \mathrm{~nm}\right)$. The instrument is also equipped with an Anton Paar HTK 16 temperature attachment facilitating the measurements at up to $1600{ }^{\circ} \mathrm{C}$.

\section{RESULTS AND DISCUSSION}

The mechanical properties and microstructures of the AAS mortars subjected to high temperatures were compared with the samples, treated only at ambient temperature, marked as 'Ref' (Table 1). The compressive

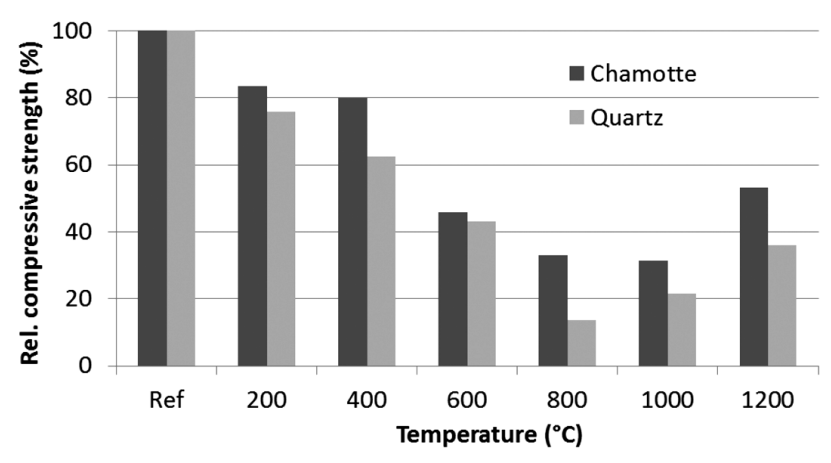

Figure 1: Comparison of the relative residual compressive strengths of AAS mortars after high-temperature treatment

Slika 1: Primerjava relativnih preostalih tlačnih trdnosti AAS-malt po obdelavi na visoki temperaturi

Table 1: Compressive and flexural strengths of AAS mortars with different aggregate types after exposure to high temperatures

Tabela 1: Tlačna in upogibna trdnost AAS-malt $\mathrm{z}$ različno vrsto agregata po izpostavitvi visokim temperaturam

\begin{tabular}{|c|c|c|c|c|}
\hline \multirow{2}{*}{$\begin{array}{c}\text { Tempera- } \\
\text { ture }\left({ }^{\circ} \mathrm{C}\right)\end{array}$} & \multicolumn{2}{|c|}{$\begin{array}{c}\text { Compressive strength } \\
(\mathrm{MPa})\end{array}$} & \multicolumn{2}{|c|}{ Flexural Strength (MPa) } \\
\cline { 2 - 5 } & Quartz & Chamotte & Quartz & Chamotte \\
\hline Ref & 73 & 92 & 9.6 & 10.4 \\
\hline 200 & 55 & 77 & 4.4 & 7.5 \\
\hline 400 & 46 & 74 & 3.8 & 6.2 \\
\hline 600 & 31 & 42 & 2.6 & 4.8 \\
\hline 800 & 10 & 31 & 1.7 & 4.2 \\
\hline 1000 & 16 & 29 & 1.0 & 5.0 \\
\hline 1200 & 26 & 49 & 2.9 & 12.5 \\
\hline
\end{tabular}




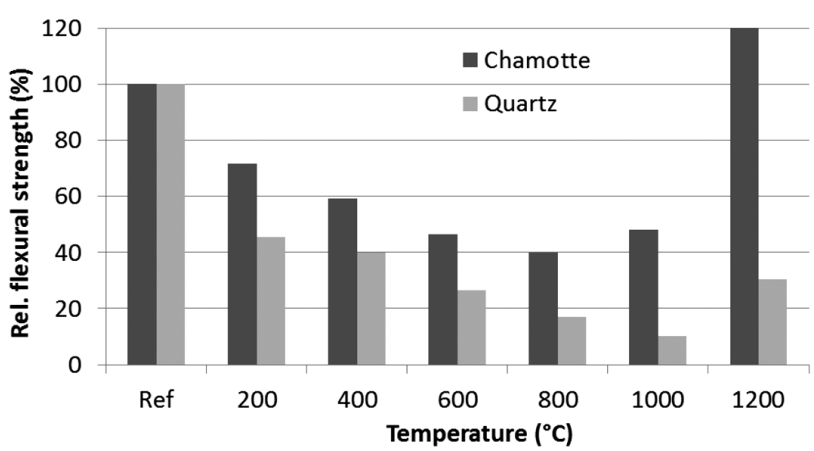

Figure 2: Comparison of the relative residual flexural strengths of AAS mortars after high temperature treatment

Slika 2: Primerjava relativne preostale upogibne trdnosti AAS-žlinder po obdelavi na visoki temperaturi

strengths of the AAS mortars with chamotte reached 92 $\mathrm{MPa}$ which is very close to the value for the AAS matrix itself ${ }^{8}$ therefore, the aggregate seems not to be a limiting factor for the mechanical properties of such composites. On the contrary, quartz sand caused a strength decrease by $19 \mathrm{MPa}$. This might be explained with weaker contacts between the AAS matrix and the aggregate. After the exposure to an elevated temperature, the compressive strengths gradually decreased (Figure 1). The trend, however, appeared to be the same for both composites; therefore, it can be attributed to the dehydration and de-
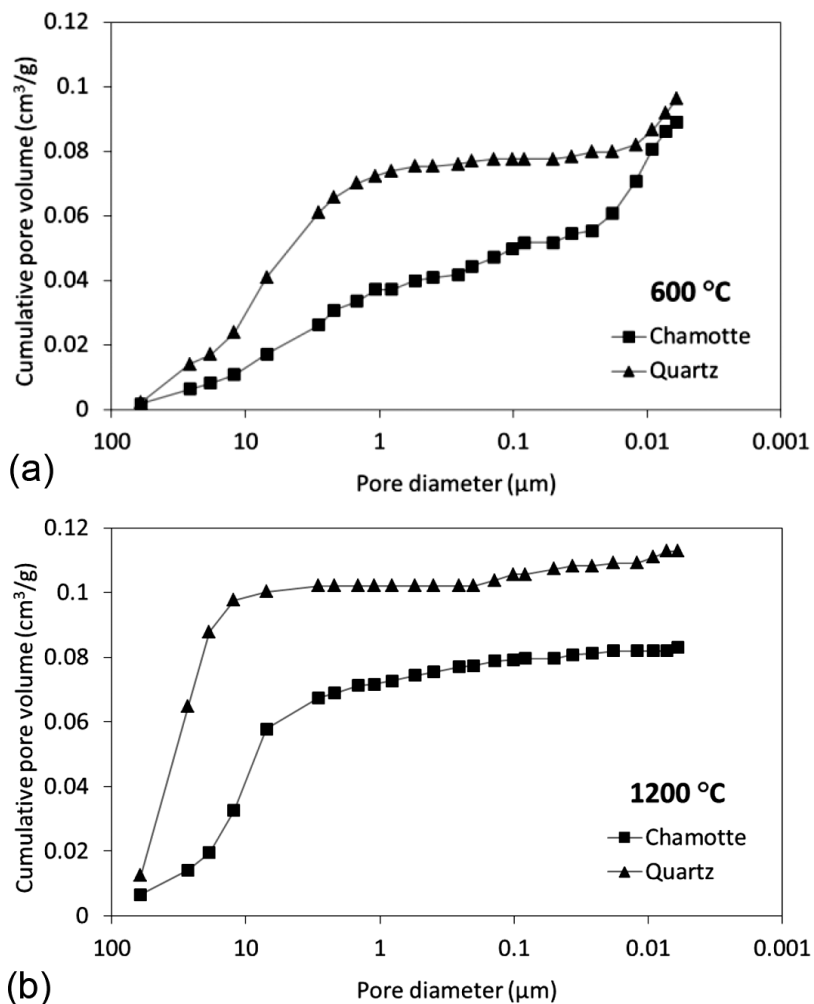

Figure 3: Differences in pore distribution for AAS mortars with quartz and chamotte after exposure to $600{ }^{\circ} \mathrm{C}$ and $1200{ }^{\circ} \mathrm{C}$, respectively

Slika 3: Razlike v razporeditvi por v AAS-žlindrah s kremenom in šamotom po izpostavitvi na temperaturo $600{ }^{\circ} \mathrm{C}$ in $1200{ }^{\circ} \mathrm{C}$ composition of the AAS matrix. The strength decrease of the AAS composite with quartz above $600{ }^{\circ} \mathrm{C}$ was partly caused by the phase transition of quartz at $573{ }^{\circ} \mathrm{C}$ ( $\beta$-quartz $\rightarrow \alpha$-quartz), accompanied by a change in the volume. The exposure of the AAS material to temperatures above $800{ }^{\circ} \mathrm{C}$ caused an increase in the strength that reached $53 \%$ of the original strength for the AAS with the chamotte aggregate and $36 \%$ of that obtained for the AAS with quartz.

The flexural strengths of both AAS composites treated at an ambient temperature were quite similar. After a high-temperature treatment the strengths decreased due to the decomposition processes in the matrix; however, in the case of the quartz aggregate the strength deterioration was more pronounced (Figure 2). The minimum value for the chamotte composite was achieved at $800{ }^{\circ} \mathrm{C}$ when the strength dropped to $40 \%$ of the reference value, while the mortar with quartz exhibited the minimum strength at $1000{ }^{\circ} \mathrm{C}$ reaching only $10 \%$ of the original value. An enormous difference in the mechanical performance was observed after the exposure to $1200{ }^{\circ} \mathrm{C}$. The flexural strength of the chamotte composite exceeded the reference value by $20 \%$, while the strength achieved for the quartz sample remained very low.

The pore distribution obtained by means of mercury intrusion porosimetry up to $400{ }^{\circ} \mathrm{C}$ resembled the porosity of the matrix itself. ${ }^{8}$ The main difference in the pore distribution appeared after the exposure to $600{ }^{\circ} \mathrm{C}$ (Figure 3). There was an increase in the pore volume in the range of large capillary pores $(1-10 \mu \mathrm{m})$ for the quartz composite, which can be clearly attributed to the reversible phase transition to high quartz, followed by an increase in the aggregate volume by approximately $4.5 \% .{ }^{10}$ After the exposure to $1200{ }^{\circ} \mathrm{C}$, the major part of the porosity can be attributed to the pores $>10 \mu \mathrm{m}$. This is mainly caused by the shrinkage of the matrix during the crystallization of the new phases. However, the total porosity of the chamotte composite was much lower and it also corresponded to the differences in the achieved mechanical parameters.

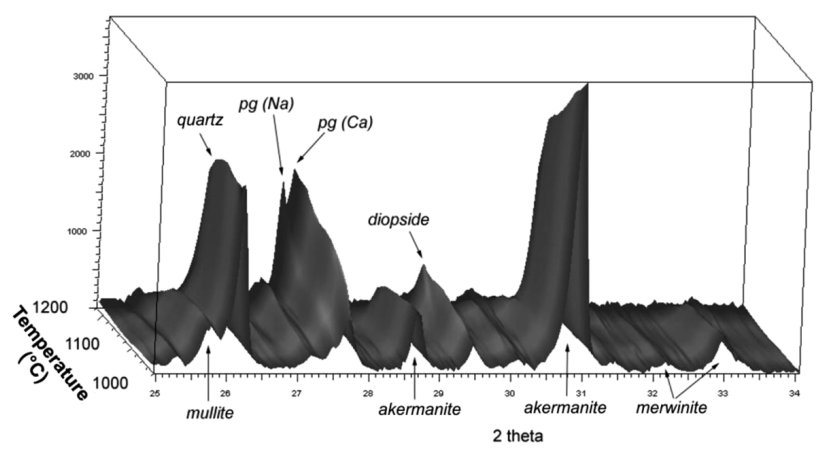

Figure 4: High temperature XRD of AAS mortar with chamotte aggregate (pg - plagioclase)

Slika 4: Visokotemperaturna XRD in AAS-malta s šamotnim agregatom (pg - plagioklas) 


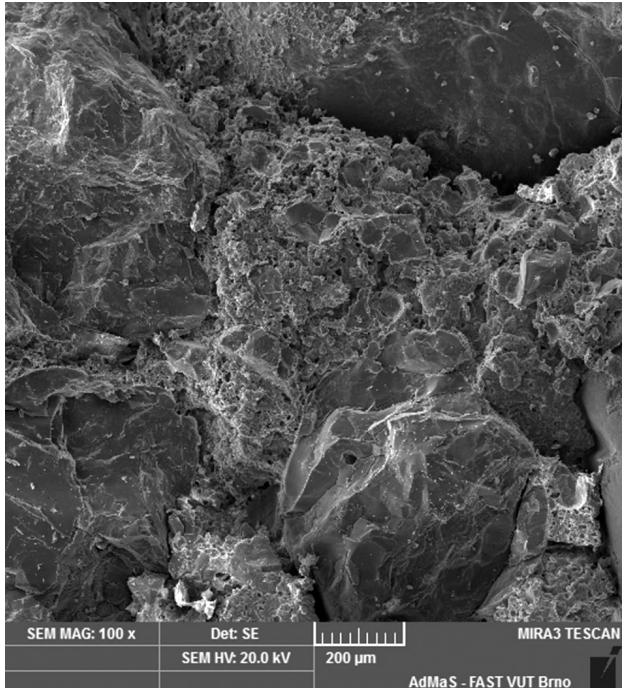

Figure 5: Microstructure of AAS mortar with quartz aggregate after exposure to $1200{ }^{\circ} \mathrm{C}$ (SEM)

Slika 5: Mikrostruktura AAS-malt s kremenovim agregatom po izpostavitvi na $1200^{\circ} \mathrm{C}(\mathrm{SEM})$

The changes in the mineralogical phases of the AAS mortars were observed by means of a high-temperature $\mathrm{XRD}$ analysis. Since quartz is quite an inert phase that does not react with the AAS matrix even at a very high temperature, there was practically no difference between the XRD patterns of the quartz composite and the AAS matrix itself. ${ }^{8}$ On the other hand, chamotte contains two main crystalline phases, quartz and mullite. The latter is not stable when such a high concentration of alkalis is present in the material and reacts with the AAS matrix to form two plagioclase phases, albite and anothite, at temperatures exceeding $1000{ }^{\circ} \mathrm{C}$ (Figure 4). These two phases were not observed in the XRD pattern of the pure AAS matrix giving the proof of such an explanation.

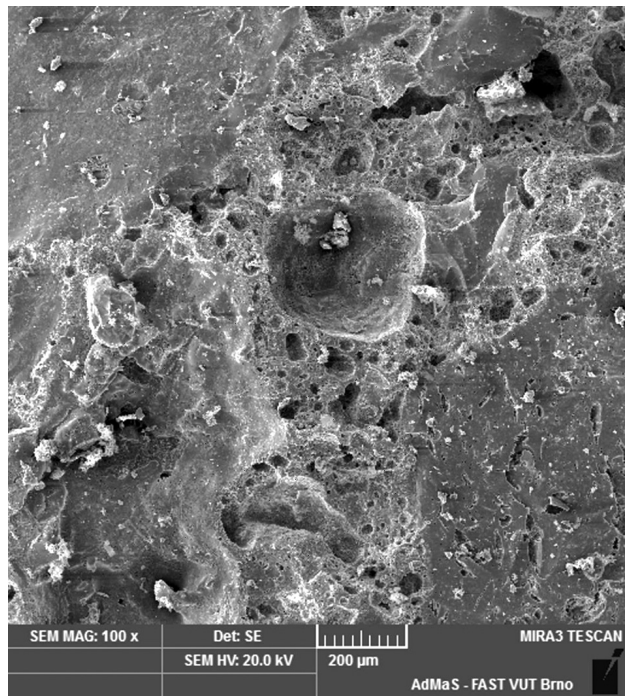

Figure 6: Microstructure of AAS mortar with chamotte aggregate after exposure to $1200{ }^{\circ} \mathrm{C}$ (SEM)

Slika 6: Mikrostruktura AAS-malt s šamotnim agregatom po izpostavitvi na $1200{ }^{\circ} \mathrm{C}(\mathrm{SEM})$
Since the melting point of albite is in the range of $1100-1120{ }^{\circ} \mathrm{C},{ }^{11}$ it caused a partial fusing of the contact zone between the aggregate grains and the matrix during the heating to $1200{ }^{\circ} \mathrm{C}$.

The microstructure and morphology of the AAS mortars were investigated with scanning electron microscopy. To explain the difference in the mechanical behaviour of various AAS composites we focused on the interstitial zone between the aggregate grains and the matrix. Figure 5 shows the microstructure of the AAS mortar with the quartz aggregate. The connection between the quartz grains and the AAS matrix is very weak and it is clearly evident that a small gap is present between both phases as a result of the volume changes in quartz at $573{ }^{\circ} \mathrm{C}$. Therefore, the quartz grains can be easily pulled out of the matrix, which predominantly causes a deterioration of the flexural strength. Contrary to quartz, the surfaces of the chamotte grains were sintered with the matrix after the exposure to very high temperatures (Figure 6). This finally resulted in the formation of ceramic bonds which were so strong that a fracture of the aggregate grains occurred during the mechanical testing.

\section{CONCLUSIONS}

This study aimed to estimate the influence of the aggregate type on the behaviour of the alkali-activated slag mortars subjected to very high temperatures. The alkali-activated slag materials exhibit a much better performance compared to the concrete made from ordinary Portland cement when subjected to very high temperatures or fire. A utilization of chamotte as an aggregate in the AAS composites brought several benefits compared to quartz sand. Chamotte is a material that is produced from natural clay at $1350{ }^{\circ} \mathrm{C}$ and, therefore, it is more thermally stable than pure quartz that undergoes a phase transition at $573{ }^{\circ} \mathrm{C}$. From the viewpoint of the mechanical properties, the chamotte aggregate did not limit the mechanical parameters of the AAS paste at temperatures of up to $1000{ }^{\circ} \mathrm{C}$ and it even considerably improved the flexural strength of the composite at $1200{ }^{\circ} \mathrm{C}$ due to the sintering of the aggregate surface layer with the AAS matrix. Although a degradation of the material occurred upon heating, the compressive strength of the chamotte composite was higher by $15 \%$ and the flexural strength was even four times higher compared to the quartz composite after the exposure to $1200{ }^{\circ} \mathrm{C}$. Therefore, the properties of the chamotte aggregate predestine its application in the alkali-activated slag composites with an improved high-temperature resistance.

\section{Acknowledgement}

This outcome was achieved with the financial support of the Czech Science Foundation, project GA CR 14-25504S and the Ministry of Education, Youth and 
Sports of the Czech Republic under the "National Sustainability Programme I" (project No. LO1408 AdMaS UP), as an activity of the regional Centre AdMaS, "Advanced Materials, Structures and Technologies". The authors would like to thank Dr Patrik Bayer for measuring some of the microstructural data.

\section{REFERENCES}

${ }^{1}$ A. F. Bingöl, R. Gül, Fire Mater., 33 (2009), 79-88, doi:10.1002/ fam.987

${ }^{2}$ G. F. Peng, Z. S. Huang, Constr. Build. Mater., 22 (2008) 4, 593-599, doi:10.1016/j.conbuildmat.2006.11.002

${ }^{3}$ K. Y. Kim, T. S. Zun, K. P. Park, Cem. Concr. Res., 50 (2013), 34-40, doi:10.1016/j.cemconres.2013.03.020
${ }^{4}$ P. Kalifa, F. D. Menneteau, D. Quenard, Cem. Concr. Res., 30 (2000), 1915-1927, doi:10.1016/S0008-8846(00)00384-7

${ }^{5}$ K. D. Hertz, Fire Safety J., 38 (2003) 2, 103-116, doi:10.1016/ S0379-7112(02)00051-6

${ }^{6}$ M. Zeiml, D. Leithner, M. Lackner, H. A. Mang, Cem. Concr. Res., 36 (2006) 5, 929-942, doi:10.1016/j.cemconres.2005.12.018

${ }^{7}$ M. Guerrieri, J. G. Sanjayan, F. Collins, Fire Mater., 33 (2009) 1, 51-62, doi:10.1002/fam.983

${ }^{8}$ P. Rovnaník, P. Bayer, P. Rovnaníková, Constr. Build. Mater., 47 (2013), 1479-1487, doi:10.1016/j.conbuildmat.2013.06.070

${ }^{9}$ R. Zhao, J. G. Sanjayan, Mag. Concr. Res., 63 (2011) 3, 163-173, doi:10.1680/macr.9.00110

${ }^{10}$ U. Raz, S. Girsperger, A. B. Thompson, Schweiz. Mineral. Petrogr. Mitt., 82 (2002), 561-574

${ }^{11}$ J. P. Greenwood, P. C. Hess, J. Geophys. Res., 103 (1998) B12, 29815-29828, doi:10.1029/98JB02300 